\title{
HISTÓRIA E LOUCURA NA INTIMIDADE DAS \\ LETRAS: NO "HOSPÍCIO" E O ROMANCE SIMBOLISTA DE ROCHA POMBO
}

\section{History and Madness in the intimate world of the arts: "in the hospice" and Rocha Pombo's symbolist novel}

\author{
Nádia Maria Weber dos Santos* \\ O que ele (o historiador) encontra logo no início de sua investigação \\ não é um mundo de objetos físicos, mas um universo simbólico - \\ um mundo de símbolos. Antes de mais nada, \\ ele precisa aprender a ler estes símbolos.
}

Ernst Cassirer

\begin{abstract}
RESUMO
Este artigo tem como objetivo legitimar o uso da literatura como fonte histórica e traçar algumas das inter-relações possíveis entre estas duas disciplinas. A categoria da ficção, como elemento pertencente a ambas, atua como um elo que respalda esta análise. Para demonstrar estas considerações, escolheu-se a loucura como objeto e o romance simbolista de Rocha Pombo, "No Hospício", publicado em 1905, como fonte.
\end{abstract}

Palavras-chave: História Cultural; literatura; loucura; ficção.

\begin{abstract}
This article aims to legimate the use of literature as a historical source. The category of fiction, concerning to both areas, endorses this analysis. In order to demonstrate these evidences, it was selected as subject the madness and as source the Rocha Pombos's symbolist novel "No Hospíco", published in 1905.
\end{abstract}

Keywords: Cultural History; literature; madness; fiction.

* Médica psiquiatra; Professora do Curso de Pós-Graduação em Arteterapia da FEEVALE 
A relação entre história e literatura é pensada em termos da aproximação e cotejos dos elementos de narrativas de ficção com a história daquilo que um dia se passou. Considere-se o historiador, como um tipo especial de leitor que se debruça sobre um texto literário e que tem por meta tanto a narrativa deste passado como a interpretação do mesmo. Com isto ele constrói uma versão do passado, daquilo que aconteceu um dia, versão esta plausível e coerente. Sua aproximação da obra literária se faz, contudo, tendo em vista que esta é, também, um tipo especial de fonte: ela não é um mero dado ou documento "formal".

Na concepção de Pesavento (1996), o texto literário faz o historiador deparar-se com sensibilidades passadas, isto é, "possibilidade de atingir aquela 'sintonia fina' que permita captar o passado de outra forma e que deve obedecer ao que chamamos uma nova 'pedagogia do olhar"”.

Em outras palavras, a literatura traz a subjetividade e a sensibilidade do passado, daquilo que um dia foi vivido, sentido, percebido de uma outra forma, ou da forma como podia ser naquele momento. Ciente de que este novo olhar é apenas uma versão sobre o passado, o historiador tenta apreender o registro das nuanças das sensibilidades de uma época, seus valores, conceitos, noções sobre a vida dos homens e suas práticas sociais.

Fazendo esta aproximação com o objeto atual de estudo (a loucura), é a partir de uma narrativa sobre loucura que se redimensiona, de certa forma, no início do século XX brasileiro, como esta sensibilidade "fina" percorreu este tema e foi-nos apresentada por quem debruçou-se em sua observação.

Procurou-se, diante disto, historicizar a loucura com os olhos voltados para a literatura como fonte. Isto colocou em confronto as realidades sensíveis de um escritor e seus personagens, vivendo dentro de um hospício "imaginário", com as realidades concretas das práticas de exclusão institucionais - desde a criação de manicômios até a perpetração, nestes, de técnicas médico-psiquiátricas instituídas pelos detentores do saber médico.

A categoria da ficção é o ponto teórico, dentro da reflexão da História Cultural, que melhor pode fundamentar tais análises, bem como respaldar a utilização da literatura como fonte histórica.

A ficção, e no caso presente ficção literária, através de sua linguagem simbólica, coloca em evidência o poder da representação na vida cotidiana humana. Ela comporta o "estatuto do real” intrínseco à capacidade de representação de todo ser humano, isto é, seu sistema simbólico. 
Todo o sistema simbólico de representações que ela traz em si significa a projeção do que estava até então no inconsciente humano, seus sentimentos, sensações, pensamentos, maneiras de ser e ver o mundo, mais íntimos, próprios de cada um (subjetivo) e/ou de cada época (objetivo, ou o "espírito" da época). Através deste sistema imaginário, o estabelecimento da "verdade" unívoca desaparece por inteiro através da tarefa mais interessante e promissora que é o questionamento da "narrativa das sensibilidades".

Assim como a literatura comporta a ficção, a escrita histórica também comporta elementos de ficcionalidade em sua ontologia, desde que bem amparados em bases "documentais", em fontes, como preza e precisa o historiador. O entrecruzamento de história e literatura - esta como fonte das sensibilidades de um passado - se dá, pois, através do plano ficcional, onde as representações do sensível aparecem nos personagens e narrativas literárias.

Conforme refere Leenhardt, tanto a narrativa histórica como as de ficção somente existem, enquanto fenômeno social (histórico), devido a uma demanda da sociedade por representações imaginárias. Seguindo Paul Ricoeur, este autor afirma que a literatura de ficção fornece ao leitor um reconhecimento de mundos verossímeis ao seu, que o levam a um processo de identificação, numa "relação de reconhecimento, conhecimento e imaginação".(LEENHARDT, 2000, p. 47)

Mas para ele, ainda, a leitura se efetua em diferentes níveis "nos quais se exercem também diferentes competências, sensíveis, memoriais, ou enciclopédicas e, enfim, intelectuais". A leitura, assim, não se constitui no resultado de um simples processo de compreensão:

O verdadeiro saber ler, se for tomado este termo a sério, na sua complexidade, é, em realidade, a soma das variadas competências que um sujeito é capaz de realizar face a um texto literário dado. [...] Cada gênero, mais ainda do que cada obra, faz apelo a um dispositivo de compreensão ou interpretativo, diferentemente constituído. (LEENHARDT, 2002, p. 3)

Pesavento, utilizando o referencial teórico de Jauss, sustenta a afirmação de que história é sempre a construção de uma experiência, o que se 
torna bastante válido quando se trata de repensar, ou de reconstruir, sensibilidades de um outro tempo, a partir da literatura.

O historiador é obrigado a realizar sempre uma ficção perspectivista da história, dado que é impossível a existência de uma história que recolha simplesmente o passado nos arquivos [...]. Não se chega, pura e simplesmente, a fatos aprioristicamente estabelecidos por fontes. A história é, neste sentido, sempre construção de uma experiência, que tanto reconstrói uma temporalidade quanto a transpõe em narrativa. Neste sentido, argumenta Jauss, a estetização, ou a colocação em ficção da experiência histórica, é uma obra, uma construção. (PESAVENTO, 2000, p.38-9)

A literatura é um tipo especial de fonte, pois entre tantas outras funções, possui o papel de dialogar com o seu tempo, de uma forma ou de outra. Conforme Leenhardt, ela é usada, seguidamente pelos historiadores, para dar existência ao que não é claramente visível, legível, nos documentos habituais:

A literatura apresenta, neste aspecto, a vantagem de ser explícita, legítima, e, ao mesmo tempo, de pouca conseqüência, pois é claro, para cada um, que não se poderia conceder fé às ficções! A literatura é assim, a boa filha do historiador, sempre a servir, se for preciso, ou silenciosa, se necessário. Ela é, então, um objeto particularmente útil no momento de pensar ou de não pensar os movimentos que agitam, ainda que implicitamente, as calmas águas da História. (LEENHARDT, 2002, p.3)

Conforme Pesavento, ainda, o processo de representação do real que a história se propõe, envolve criação, invenção, opções, estratégias de conhecimento e pode se situar "na esfera que chamamos de produção fictícia de uma temporalidade". "Reconstruir o vivido pela narrativa é, praticamente, dar a ver uma temporalidade que só pode existir pela força da imaginação: primeiro do historiador, depois do leitor do seu texto." (PESAVENTO, 2000, p. 41)

Nada mais justo, portanto, que, nesta reconstrução de um passado "sensível", se utilize fontes que balizem este caminho, como as narrativas 
de ficção literária que, ao mesmo tempo, relatam sensibilidades da imaginação. É a imaginação (loucura) exposta pela imaginação (escrita literária), num movimento dialético que leva ao conhecimento social no tempo e, portanto, histórico, através da narrativa do historiador.

Para Leenhardt,

Olhando-se mais de perto, a literatura de ficção, considerada como documento histórico, desempenha em efeito sobre dois planos: primeiro aquele da expressão de teses ou idéias por um narrador mais ou menos onisciente. Neste caso, ele dá uma formulação clara aos discursos que provém desta cultura, do explícito ao qual o historiador gostaria de permanecer. Por outro lado, ela é o teatro daquilo que faz, realmente, o corpo da ficção: a ação. A ação não é um discurso. É mesmo difícil de reduzi-la ao discurso pois, precisamente, o modo de agir dos personagens do romance permanece infralingüístico, infradiscursivo, submetido a imponderáveis, a contradições, a contingências, a tudo aquilo do qual o discurso tem horror. Eles agem e, entretanto, esta ação tem um sentido! (LEENHARDT, 2002, p. 3)

A literatura, como uma portadora fiel de um imaginário que se encontra "do outro lado" do concreto, pode constituir-se numa "narrativa do sensível" fidedigna sobre a loucura, no momento em que mostra a voz do paciente revelada pelo personagem. O "louco", através de um discurso "não oficial", mostra o outro lado da realidade.

Em outras palavras, existe o discurso oficial, uma "instituição" (leiase cultura) consciente de normas e padrões a serem aceitos e realizados, e, em contrapartida, existe sempre uma subcorrente de fantasias inconscientes complementares.

A ficção ultrapassa, o que parece certo, a expressão consciente de seu narrador e, bem entendido, de seus personagens. Ela contém, portanto, não exatamente uma mensagem que seria, por definição, consciente e enunciada, mas um signo. A ficção sinaliza para mundos possíveis. A ficção propõe, sob a forma somente potencial de um dever ser e não de um fato, ela abre um horizonte para além do real. Em função desta possibilidade de abertura, desta capacidade de desenhar um mundo, segundo 
regras que ultrapassam o cotidiano, a ficção adquire um estatuto muito particular, na formulação daquilo que anima os movimentos de fundo da história. Ela não é profética, no sentido dos videntes, que dão o futuro já por assegurado, mas ela é visionária, na medida em que autoriza a organizar o mundo das ações e dos fins de outra forma para além daquela que existe. (LEENHARDT, 2002, p. 4)

É exatamente pelo fato de a ficção sinalizar para mundos possíveis, conter nela um símbolo e ser visionária, como Leenhardt sublinhou, é que se torna possível falar nela como um alimentador do imaginário das sociedades. Ela remete a algo que ultrapassa a formulação consciente de e sobre uma dada época; sendo assim, traz à tona as sensibilidades, mais coletivas do que individuais, mais inconscientes que conscientes, de um determinado momento histórico.

Parte-se de uma definição simples: o imaginário refere-se a um conjunto de imagens, isto é, é um depositário de imagens. Sendo assim, há duas formas distintas de pensar este "conjunto", isto é, a noção de imaginário tem uma dupla face. ${ }^{1}$

A primeira é aquela que trabalha com sua noção desde o ponto de vista do conjunto de representações coletivas forjadas por uma coletividade para expressar suas idéias, crenças e comportamentos comuns - concepção esta utilizada por historiadores e sociólogos contemporâneos. Ela diz respeito às formulações da "consciência coletiva"² a respeito de seus símbolos. Este "imaginário desde fora" representa a face voltada para o exterior, para a realidade social, possibilitando quase que uma "construção consciente" de um imaginário. Esta face realiza-se no tempo e no espaço, por exemplo, quando do surgimento de movimentos sociais e políticos, e presta-se à manipulação e jogos de poder. Em outras palavras, é possível à consciência coletiva de uma determinada sociedade construir seu imaginário a partir do que chama de "símbolos coletivos".

1 Para aprofundar estas conceituações de imaginário e símbolo ver Santos, 2005, capítulo 1.

2 "Consciência coletiva" é uma expressão utilizada por Jung (1982, p. 20 et. seq.), quando se refere ao conjunto de normas e padrões coletivos, enfim, a tudo aquilo que é socialmente e coletivamente consciente e identificado como tal. 
A segunda, tão complexa quanto a primeira, trata de uma concepção de "imaginário desde dentro", isto é, utiliza a noção de inconsciente, como matriz/fonte das manifestações humanas. Ressalta o caráter simbólico das imagens das fantasias humanas, que aparecem em suas mais variadas manifestações provindas do "âmbito" do inconsciente. Estas surgem espontaneamente na psique dos indivíduos, tomando forma, através de imagens, no mundo exterior consciente. Remete ao caráter criativo do inconsciente humano e está presente, também, na criação literária.

[...] Na verdade, a concepção do imaginário como função criadora se constrói pela via simbólica, que expressa a vontade de reconstruir o real num universo paralelo de sinais. [...]. A noção de símbolo é, pois, central e se encontra ligada à de representação [...]. Assumimos, pois, o pressuposto das representações simbólicas e alegóricas do imaginário coletivo [...]. (PESAVENTO, 1995, p. 21)

Define-se, aqui, símbolo como sendo a melhor expressão possível, insuperável numa dada época, do que ainda é desconhecido e compreende-se que ele possa surgir no momento mais complicado e diferenciado da atmosfera espiritual, social e cultural de um dado tempo Um símbolo é sempre mais do que podemos entender à primeira vista; ele não dissimula, ele revela no tempo oportuno, ele ensina. "O símbolo exprime sempre que, em sua forma, reside, mais ou menos, uma possibilidade de nova manifestação de vida, de uma redenção dos vínculos e do cansaço vital".(JUNG, 1981, p. 547).

Literatura, loucura e história cultural, todas trabalham com sistemas simbólicos, passíveis de serem interpretados em ambas as faces do imaginário. Com isto, quer-se dizer que sua inter-relação, no campo mesmo deste imaginário, pode satisfazer a meta de descortinar sensibilidades sobre a loucura, ocultadas pelas práticas sociais de exclusão.

Utilizando, ainda, o pensamento de Leenhardt para nosso enfoque analítico, pensar simbolicamente os textos literários, é resgatar os sentidos das falas dos personagens, é trazer à tona a fineza de suas sensações e de seus sentimentos a respeito da loucura, o que organizará, de certa maneira, um imaginário. Este permitirá esboçar algumas reflexões, num caminho de mão dupla, respeitando aquelas duas faces. 
O primeiro conjunto de reflexões leva pelo caminho de perceber o sentido que o escritor quis dar, conscientemente, sobre a temática da loucura. Mas, também, permitirá vislumbrar como se dá a organização social a respeito da loucura, sem cair na falácia, obviamente, de que a literatura explica o social.

O outro sentido, nesta via de dupla mão, é aquele que resgata a sensibilidade do próprio louco sobre si mesmo e sua "loucura".

As múltiplas experiências que uma pessoa tem com a loucura - e não menos desprovido de sentido é falar-se nas experiências com a internação psiquiátrica pela qual passa ou passou - não somente deixa marcas em sua vida "real", esta entendida como uma vida vivida externamente em seu meio social, mas também em seu psiquismo. O que afetará, sem dúvida, tudo aquilo que ela será no futuro, que ela sentirá por si mesma, que ela perceberá no mundo, daqui para frente. Enfim, deixará marcas em seu imaginário.

Também múltiplas são as formas pelas quais a loucura deixa-se transparecer nos gestos, atitudes e delírios das pessoas que habitam "a casa dos loucos". E é neste mundo imaginário, onde se permite "ler o delírio" de um louco, que se identifica um mundo de transgressões, transgressões estas, inclusive, das normas coletivas. Assim, é nesta expressão simbólica onde se pode perceber a sensibilidade mais fina sobre o que o "louco" (ou um paciente na situação em que se encontra) pensa e sente.

Ler o delírio do louco, em textos literários é, de certa forma, um desafio, que orienta uma leitura em direção ao simbólico, pois o que se chama delírio, nada mais é do que conteúdo simbólico do imaginário de uma pessoa (no caso, de pacientes internados, que serão lidos em cada uma das obras), retratando, muitas vezes, um imaginário coletivo. Na verdade, este "sistema simbólico" constituinte do imaginário de um paciente, traz à tona a sensibilidade sobre a loucura de certa época dada, onde ele se insere na corrente histórica que lhe deu origem. E mais ainda se estiver colocada na fala de um personagem literário. ${ }^{3}$

$$
\text { *** }
$$

3 Este artigo é uma adaptação de algumas idéias que se originam na tese de doutorado "Histórias de Sensibilidades: espaços e narrativas da loucura em três tempos - Brasil, 1905, 1920, 1937", defendida em 2005 no Programa de Pós Graduação em História da UFRGS. 
Se ele é realmente doido, é um doido bem esquisito [...]. Só Deus poderia dizer-nos o que há de grande e doloroso na alma daquela criatura... tão original, ou tão singularmente dotada de excelências que se destacou do comum para fazer jus a um hospício [...]

Rocha Pombo - No Hospício

Rocha Pombo (1857-1933), paranaense, foi um historiador filólogo e um escritor engajado na política da Monarquia e da República. Publicou muitos ensaios e livros, durante sua vida, bem como editou jornais e participou de revistas consagradas ao Simbolismo Brasileiro. Pertenceu à antiga Academia Paranaense de Letras. Embora a crítica daquela época tenha se interessado pouco por um de seus principais romances, No Hospício, quando de sua publicação em $1905^{4}$, Pombo foi considerado, ainda vivo, um escritor importante das Letras Brasileiras. Resgatam-se, com ele, imagens da loucura expressas pela escrita de um literato, que nunca passou por internações psiquiátricas ou práticas de exclusão social, porém foi sensível a suas manifestações.

$\mathrm{O}$ romance revela um certo pano de fundo: o sanatório hospeda o protagonista "louco", Fileto, um rapaz sensível e "filósofo-místico", levado à internação compulsória pela família, e também o narrador, que se internou aí voluntariamente, a fim de ter a maior aproximação possível com este "louco", que ele queria conhecer melhor. Isolado em sua "cela", Fileto escrevia. Escrevia em uma quantidade grande de cadernos, registros estes de cunho pessoal, que davam conta de sua vida e do mundo em que vivia, ao mesmo tempo em que mostravam grande capacidade de reflexão filosófica e mística. Em No Hospício, considerada sua principal obra literária, RP "assume" o discurso do louco: a subjetividade do escritor mesclando-se à subjetividade do personagem-narrador, que se finge louco para poder entrar no manicômio.

O seguinte trecho surge no início da "saga" do "narrador-historiador", quase um biógrafo, um anônimo na narrativa ficcional, dentro da instituição em que se interna voluntariamente, motivado pela satisfação de uma curiosidade, a de travar relações com um "louco" instigante e misterioso, porém pacato.

4 Utiliza-se a segunda edição da obra, de 1970, publicada pelo Instituto Nacional do Livro e organizada/prefaciada por Afrânio Coutinho. 
Estranho, não é assim! Mas, não se imagine que me foi muito difícil fingir os desequilíbrios, que atestam a loucura. Ser louco é o que há de mais fácil no mundo. Parece que quando penetrei naquela casa, conduzido por um amigo, já eu não era o mesmo homem, que ali costumava ir são: tudo em mim - o meu andar, a minha voz, os meus gestos, o meu olhar - tudo era de um verdadeiro louco. Creio que se dava em mim um fenômeno muito fácil de ser constatado por qualquer pessoa inteligente, que o deseje. A certeza de que o médico me tinha por louco, mudara inteiramente o meu moral e todo o meu ser...

Demais, eu me senti logo tão bem no meu novo papel...Se eu falava, o médico me ia escutando com tanto interesse...Eu podia dizer as coisas mais leais, mais finas, mais altas...Podia discutir moral, religião, ciências exatas e afirmar as coisas mais belas ou mais absurdas...Podia mostrar-me bem materialista e ateu, ou fazer-me beato e infinitamente místico...Podia revessar palavras tímidas ou gritar como um possesso... - Tudo que eu fizesse era de doido...Podia zangar-me, ser brusco, ir até a insolência...Podia fazer críticas irreverentes ao nariz do doutor, chamá-lo de ilustre ou de besta, pedir-lhe um cigarro ou mandá-lo às favas... - tudo me era permitido. Oh! Que vida deliciosa! Eu chorava, eu ria à vontade, sem que ninguém se importasse com a minha gargalhada ou com o meu pranto. (POMBO, 1970, p. 28)

Os indícios daquilo que Rocha Pombo chamou de loucura, tornam-se já explícitos nestas linhas, ainda no início do romance. Para ele, "fingir os desequilíbrios que atestam a loucura", está diretamente relacionado ao aval do médico, isto é, a subjetividade do narrador foi transformada assim que colocada em relação com a outra subjetividade, mais "poderosa".

Em outras palavras, o que o personagem expressa é a certeza de que se o "douto", detentor do saber e do poder de avaliação, tinha-o como louco, então assim ele procederia espontaneamente! A frase "A certeza de que o médico me tinha por louco, mudara inteiramente o meu moral e todo o meu ser...", mais do que um expediente literário revela a sensibilidade do autor para o fato do quanto a autoridade médica, neste período da história brasileira, já era sentida como forte e detentora de um poder sobre os diagnósticos da psique humana.

Embora, possamos inverter esta "verdade" ao perguntar: mas, se o narrador não era "louco", apenas fingia ser um, como foi que o médico não 
o percebeu? Fingir ou ser daria a mesma representação no imaginário da Medicina? Estaria, assim, a Medicina da época, segura de seus diagnósticos? Não estaria, nisto, uma crítica velada aos psiquiatras? Seria muito profícuo se tivéssemos alguma pista sobre a gênese deste romance, vinda pelo próprio escritor, para além das opiniões e análises dos críticos literários - aliás, poucos foram aqueles que se debruçaram sobre a obra de RP. Mas infelizmente não foi encontrada, em fontes pesquisadas, nenhuma menção do próprio autor à escrita genética de sua obra, nem de seu romance. Desta forma, este é analisado a partir das impressões que deixa em sua leitura, marcas de sua sensibilidade, cotejadas com a história de sua vida e obra, comentada por alguns críticos literários da época.

O narrador fala que assumiu seu "novo papel", identificando assim um teatro, uma simulação, uma "não-verdade", uma representação. É a ficção dentro da ficção. RP, ao lidar com isto, mostra suas convicções e idéias, talvez aquilo que faltasse no mundo "sério" e formal das instituições, "Tudo me era permitido, oh! Que vida deliciosa!", inclusive denunciar a literatura através dela mesma, ou mesmo a loucura e as práticas de exclusão sobre ela, simulando uma, isto é, passando-se por louco, sofrendo as agruras de uma internação manicomial.

Como se fosse um misto de romance psicológico, romance simbolista, romance-ensaio aos olhos dos críticos, pode ser também compreendido como um romance feito a partir das "escrituras de si" de um louco, em situação de "exílio manicomial". Nele, o autor redimensiona muitas questões sobre a loucura, sobre religiosidade, além de seguir seus preceitos simbolistas, sobre arte e estética, com fartos "elogios ao símbolo", como na seguinte passagem: "Sim, a harmonia do símbolo, o ritmo espiritual e intangível da idéia é independente da palavra. A palavra não deve ser para a alma senão um sinal misterioso, muito discreto, muito austero, muito augusto, só perceptível à visão dos espíritos." (POMBO, 1970, p. 47)

Um excerto, quase filológico de sua própria obra, aparece como um "pacto de leitura", posto como advertência, no início da primeira edição do romance No Hospício, em 1905 - aliás, única edição do livro, du-

5 Para um de seus críticos, Massaud Moisés, esta e outras passagens que versam sobre "símbolo" representam uma "profissão de fé" ao pensamento de Mallarmé, um dos inspiradores do Simbolismo brasileiro. 
rante a vida do autor. Refere-se ao narrador da história, personagem criado por Rocha Pombo, e às obras que deixou escritas, além de "No Hospício", provavelmente aquelas que ele escreveu durante sua estada no manicômio e que serão mencionadas mais adiante.

Há alguns meses, falecia nesta capital, obscuro e quase na miséria, um homem, cujo nome nunca se pôde saber. Entre os papéis que deixou, encontrou-se uma farta coleção de manuscritos inéditos, sendo o que segue, sob o título de No Hospício, um dos mais interessantes. Traz na última folha a data de 1900; mas, pela cor das primeiras tiras, bem se vê que é obra em que o autor levou algum tempo a trabalhar. A letra é só legível à custa de muito esforço e paciência, e há muitas palavras que nos foi impossível decifrar, e até períodos inteiros que tivemos de suprimir por ininteligíveis. Rio, junho $1901 .{ }^{6}$

Para a maioria dos críticos, o livro mais original de Rocha Pombo é, sem dúvida, este romance. Peça representativa do simbolismo na ficção brasileira, como afirma Afrânio Coutinho, na apresentação da edição ora trabalhada, "é livro altamente espiritualizado, intensamente cerebral, na linha do romance-ensaio e de análise psicológica. A trama é quase inexistente e, na verdade, só serve para dar motivo a largas divagações filosóficas, a aventuras de pensamento, a poemas em prosa, no gênero que o simbolismo tanto explorou".

De certa forma, as críticas que Rocha Pombo recebia como historiador, dizendo que seus textos históricos eram muito fluidos e romanceados, faziam-no ser um bom escritor de ficção - embora também como escritor haveria de ser criticado.

6 Esta edição não foi encontrada. Na segunda edição, o organizador omitiu esta "advertência” do autor. Este excerto é citado por Massaud Moisés em MOISÉS, Massaud. A Literatura brasileira: o Simbolismo. São Paulo: Cultrix, 1966. v. 4. Este crítico empenha-se em dizer que esta é uma minúcia técnica, um "truque romântico" - o de lembrar que o que vai se ler é fidedigno e verídico - que ajuda a sustentar a impressão de que o romance não passa de um "extenso monólogo interior, em que o narrador reconstitui sua traumatizante experiência num sanatório de doentes mentais". Ele acrescenta ainda: "como não seria muito verosímil o romancista internar-se num hospício, mesmo que levado pelo objetivo do narrador, mandou este em seu lugar, que assim se tornaria uma espécie de seu heterônimo." Estas colocações serão comentadas de forma mais profícua ao longo do capítulo. 
Foi Tasso Silveira quem salientou este aspecto, na época, pois fazendo uma crítica positiva ao autor, aproximou suas duas facetas, a de ficcionista e a de historiador. Com isto, contrariava aos outros, que viam exatamente nesta "mistura" o defeito de sua obra. Refere:

No terreno da historiografia patrícia, também por destino inevitável, situou-se Rocha Pombo na posição, que foi a de um Michelet na França e a de um Oliveira Martins em Portugal, de recriador e não apenas narrador do passado. O polo oposto na historiografia brasileira contemporânea será, porventura, representado pela figura de Capistrano, o estrito pesquisador, severamente atento ao documento. $\mathrm{O}$ documento puro, no entanto, não contém todo o passado. Há o imponderável, o universal, o eterno de cada momento de história, e este raramente o documento o apreende, cabendo ao historiador o surge et ambulat, que fará de um instante morto de outrora uma palpitante realidade de nosso espírito. Para este ato de magia ou milagre, estão melhor preparados os evocadores - poetas, capazes de viver no mistério do seu próprio ser o episódio evocado, de maneira a dar-lhe sangue e vida quando o traslada para a dramática representação histórica." (apud CARDIM, 1958, p. 42)

Nesta afirmação, ficam ressaltadas as características de ficcionista - simbolista - na obra do historiador, equação esta que, de certa forma, pode ser invertida, para dizer que sua "veia" de ficcionista também comporta muito de seu estilo de historiador. Características estas que são bemvindas a reflexão de história cultural, onde se tenta trabalhar a narratividade da ficção numa aproximação fecunda com os dados históricos, sobre a loucura em texto literário.

O Simbolismo foi uma tendência estética de origem francesa, comum às literaturas ocidentais durante os últimos anos do século XIX. Sendo a corrente à qual o autor se filia, como compreendê-la e relacioná-la ao contexto deste trabalho?

Introduzindo a temática, Andrade Muricy lança-nos ao outro lado do mundo, onde as vagas dos movimentos começam e respingam aqui, do outro lado do Atlântico. "É preciso lembrar que o jogo de influências européias sempre pôde ser observado nesta tradição", diz ele, referindo-se à 
literatura brasileira. Desta forma, o simbolismo surgiu naquele fin de siècle XIX, na França, sob forte influência de Baudelaire.

A renovação dos valores poéticos, iniciada por Baudelaire, nela confirmado pela influência de Egar Poe, manifestou-se sob influxos vários: de Verlaine, de Mallarmé, de Rimbaud. A vaga do fundo, o maremoto estético tingiu-se das cores requintadas daquele fin- de -siècle. Naquele crepúsculo do século das luzes, que foi positivista, cientificista fanático, adorador totêmico das próprias invenções e descobertas, naturalista e ideólogo, descendente de Jean Jacques Rousseau, acenderam-se luzes outras, de cores delicadas, raras, luzes de espiritualidade e de misticismo. (MURICY, 1952, p. 17-8) ${ }^{7}$

Aparecendo com vestígios do espírito romântico, o Simbolismo foi uma revolta contra o positivismo e o objetivismo, revolta que através de uma linguagem ornada, altamente metafórica e muitas vezes exótica, iria dar grande relevo às preocupações espirituais. Nos termos da evolução européia, que continuava a se refletir no Brasil, o Simbolismo reagiu contra as correntes analíticas de meados do século XIX, assim como o Romantismo reagira ao Iluminismo que havia triunfado no século XVIII. Ambos os movimentos exprimiram a desilusão em face das vias racionalistas e mecanicistas que se vinculavam na prática à ascensão da burguesia.

Bosi afirma ser "interessante" o apelo que os simbolistas fazem à esfera da anormalidade, tanto espiritual como física, situação esta que permite aos personagens acessarem uma vida "diferente" e "superior". O elogio da loucura, diz ele, principalmente quando esta aparece em matizes esquizofrênicos, "vira lugar-comum nessa ficção que dá resolutamente as costas ao cotidiano e ao terra-a-terra". (BOSI, 1994, p. 292)

Diferentemente da poesia, este fato choca no romance, segundo o autor, pois vai contra a sua própria tradição, que, desde o século XVIII, se tem mostrado comprometido com as realidades sócio-históricas, mesmo na sua variante passional e romântica.

7 Além destas "influências", ainda se pode citar Nietzsche, Dostoiévski, Strindberg e Wagner. José Veríssimo não apreciava nem o ideário e nem a estética simbolista e chamou a corrente de "produto de importação". (apud BOSI, 1994, p. 268). 
Prova cabal é o romance No Hospício, cujo autor foi - irônica e curiosamente - um historiador, "Um dos nossos mais conspícuos historiadores", que herdou de Poe e Hoffmann "apenas o gosto narrativo pelo excepcional (um hospício onde um jovem sensível foi criminosamente internado pelo pai), mas não foi capaz de imitar-lhes a arte de sugerir atmosferas pesadelares, pois carecia de recursos formais para tanto". (BOSI, 1994, p. 294)

Em consequiência do repúdio da objetividade em arte, os simbolistas acabam recolocando em relevo a primazia das verdades subjetivas. Mas, ao mesmo tempo, os artistas contrapõem-se ao emocionalismo e ao convencionalismo da linguagem metafórica do Romantismo, o que acaba por conferir uma distância entre as duas correntes, na medida em que a "viagem subjetiva" no Simbolismo é, antes de tudo, uma incursão às camadas mais profundas da psique.

O símbolo, que povoa a literatura desde sempre, e é "considerado categoria fundante da fala humana e originariamente preso a contextos religiosos", assume nesta corrente a função chave de vincular as partes ao Todo universal que, por sua vez, confere a cada uma o seu verdadeiro sentido. Mas seu uso "quase iniciático", como coloca Antônio Cândido, confere uma maior imprecisão ainda ao movimento que leva seu nome. "Toda poesia é de alguma forma simbólica, e o simbolismo é um dos cernes da linguagem poética, ocultadora e alusiva por excelência”. (CÂNDIDO, 1964, p. 128)

O resumo da obra feito por Massaud Moisés é como segue:

O narrador, impressionado com Fileto, internado injustamente no hospício, consegue também internar-se a fim de acompanhálo nos transes da "loucura". À proporção que se conhecem melhor, vai-se revelando todo o maquiavelismo do pai de Fileto ao encarcerá-lo entre doidos, e todo o drama subjacente: Alice, irmã e muito amiga de Fileto, apaixonara-se por um moço que tivera o mesmo destino do seu irmão. Com efeito, o doido que urrava sem parar, era seu namorado, igualmente posto no hospício pelo malevolente de seu pai. Finalmente, o moço suicida-se quando sabe da morte da bem-amada. $\mathrm{O}$ narrador sai do hospício, tenta em vão demover o progenitor de Fileto, viaja para a Palestina e, ao regressar, tem notícia que o louco havia falecido. Esse entrecho, por si só linear e com um tudonada de folhetinesco, ainda mais se enfraquece pelo fato de compor algo como um segundo plano do romance. É através 
de fiapos de conversa, informações soltas, casuais, que vamos tomando ciência do que vai correndo atrás dos diálogos entre o narrador e Fileto. (MOISÉS, 1967, p. 251)

A última frase desta citação foi também a primeira "impressão de leitura" que se teve após a primeira leitura do romance. Realmente, é através de pequenas pinceladas da obra, no meio de grandes "monólogos", que se vai tomando ciência do enredo propriamente dito e seu desenlace. E foram estas "pistas" de leitura que nos aproximou da análise das sensibilidades buscadas sobre a loucura, nesta época brasileira de virada de século, onde a literatura foi muitas vezes fundamental para a compreensão de nossa sociedade.

A tarde caía lentamente, lúgubre como os próprios ares do hospício. Naquele instante devia estar a caminho do cemitério o préstito fúnebre...Ah! Sagrado descanso da morte para os que sabem sentir profundo esta penitência da vida! Como devia andar aquele ente sereno e radioso da sua redenção. Quem sabe se será assim...Mas para que estrela te mudaria tu, oh cândida criatura? (POMBO, 1970, p. 226)

Os "ares do hospício" lembram, em muitos textos historiográficos, este acima descrito... Locais lúgubres, sombrios, úmidos. Poucas descrições os contemplam de forma diferente. Apenas a sensibilidade dos autores, escritores familiarizados com a loucura, é que distribuem nuanças nas narrativas sobre manicômios.

No início eram apenas Sóror Teresa, o narrador e Fileto. Três personagens, três vidas que se cruzam. Um pano de fundo, o hospício. Ou este também seria um personagem?

Embora os críticos tenham sido enfáticos ao dizer que este romance não possui um enredo, pode-se bem entendê-lo com a seguinte estrutura dramática: o lugar em que ocorre toda a história, em suas 310 páginas, é o interior de um manicômio, não identificado por nome ou lugar - seria, então, o "hospício imaginário" do autor. Não há uma temporalidade definida, não se sabe quando a história se passa, somente algumas pistas são dadas, neste sentido, que remetem à temporalidade, como por exemplo, a referência a escritos de Nietzsche, que é um filósofo morto em 1900 - outras ques- 
tões quanto ao tempo do romance, referem-se a pistas que levam à história da psiquiatria e manicômios, no Brasil. Há três personagens no início sóror Teresa, narrador e Fileto e são estes mesmos que terminam o romance, com a morte deste último, mas há personagens secundários que possuem, também, funções bem definidas na trama: a família de Fileto que vai visitá-lo no manicômio [constituída pelo pai - aquele que detém todo o poder familiar e que tem o dinheiro, portanto, é ele que tem a autoridade de internar o filho - , a mãe, um irmão e uma irmã menor, com a qual Fileto tem grande afinidade], o diretor médico do manicômio, o louco do quarto em frente ao de Fileto e o amigo do narrador - responsável pela internação voluntária deste no hospício.

Há a exposição do problema, que consiste no desejo do narrador aproximar-se e travar amizade com o paciente que lhe inspira indagações sobre a alma humana, a fim de trocar com ele reflexões e os textos que escrevem. A peripécia (do grego peripeteai, significando incidente, ou aquele lance da narrativa que altera o enredo, mudando a face das coisas, a ação e a situação dos personagens, em suma, os altos e baixos da história). Neste caso, é o momento em que, em meio a grandes divagações sobre a vida e a morte, a loucura, Jesus e o espírito humano, atinge-se um clímax, onde o narrador e Fileto já estão muito amigos e planejam sair do hospício e fazer uma viagem ao oriente, para que Fileto possa morrer na Palestina. A lise, ou solução do problema apresentado, consiste na saída do narrador do hospício e sua viagem ao Oriente Médio, e a morte de Fileto dentro do manicômio. ${ }^{8}$

No começo da história, Sóror Teresa não entendia por que Fileto era um louco, ou considerado como tal. A própria família colocou-o lá como Lima Barreto e TR o seriam e sem dúvida tantos outros também... Mas por quê? Ela não compreendia...

"Para não envergonhar a família", conta ao narrador. Família rica e nobre. Estranha maneira de tratar um filho, diz Sóror Teresa. Pois se ele era considerado louco apenas porque caminhava pelas ruas a esmo, estudava muito e não se trajava como a família gostasse, então ela pedia que lhe explicassem que loucura era esta.

8 Para maiores detalhes sobre este ponto de vista para análise de contos, romance e narrativas em geral, ver Von Franz (1990) e Propp [19-?]. 
Na história manicomial brasileira, a hospitalização dos considerados loucos atendeu as reclamações deste gênero, isto é, contra seu trânsito pelas ruas, como já se teve oportunidade de ver. Relata Tácito Medeiros que, já em 1835, o doutor J.F.Sigaud publicou um artigo no "Diário de Saúde" contendo reflexões acerca do livre trânsito dos doidos pelas ruas da cidade do Rio de Janeiro, onde dizia: "a classe desgraçada dos loucos [...] embuçados com grotescos andrajos, excitam as risadas dos viandantes [...] ou a torrente de grosseiras injúrias e ridículos epítetos”. (MEDEIROS, 1977, p. 5-6)

Parece claro que os cidadãos loucos eram punidos pelo mal estar que causavam, e não pelos sintomas que apresentavam. Era inconveniente o trânsito destas pessoas pelas ruas, e seu recolhimento a "gaiolas humanas, postas na vizinhança de um cemitério e por baixo de enfermarias ajoujadas de doentes" suscitava novos problemas.

Foram criados, então, hospícios, mas que tiveram, como se pode ver, a mesma função das prisões e "gaiolas de loucos". RP escreveu seu romance num momento em que os manicômios brasileiros estavam quase todos erigidos, inclusive com população acima daquela programada. Sua "sensibilidade" de escritor-historiador fez com que descrevesse a prática de exclusão que ocorria na sociedade, que, se não era mostrada explicitamente - uma vez que já havia hospícios -, era então constituinte, em sua forma implícita, do seio das famílias.

"Mas era só isto que ele fazia: só vagueava pelas ruas?", perguntou o narrador a sóror Teresa.

Só, é exato [...] mas a questão é que ele saía mal trajado, e muitas vezes dizem que as irmãs o encontravam assim, e voltavam chorando para casa [...] as coitadinhas [...]. Afinal a família cansou e o remédio foi este - entregá-lo ao hospício. Ao menos aqui ele não sofre e não envergonha a família [...] (POMBO, 1970, p. 23)

Fica explícito neste parágrafo do texto que a exclusão servia à família. Mas um paradoxo estranho, é aí colocado: não "envergonhando a família”, Fileto não sofria. Sendo assim, o hospício passa a ser, ou aparece como, um "bom lugar" ao louco, onde este escapa, ele também, das incomodações e críticas familiares. Como se observa no fim da narrativa, ele opta em morrer no manicômio a ter que voltar para o lar. 
O romance assim começa, com a "irmã de caridade", prestadora de cuidados aos enfermos desta instituição ficcionalizada por Rocha Pombo, conversando com o narrador que, ao visitar o hospício com certa frequiência, interessara-se por este doente, de nome Fileto, que lhe parecia uma "criatura extraordinária".

Soror Teresa, "de olhar nublado de uma piedosa desconsolação", não se importava de dar as informações que ele pedia; e ela, em sua alma caridosa, também nutria muita curiosidade por este estranho paciente.

É um louco tão discreto [...] tem caprichos tão finos [...] que tem hábitos tão regulares e esquisitos, gestos tão graves e meditativos; que tem olhar tão meigo - que me deixa horas a cismar...Quem sabe lá que mistério anda ali! Quem sabe lá que estranho suplício estão impondo àquela miserável alma! [...],

dizia ela, no primeiro diálogo formulado por RP em seu romance simbolista.

O narrador e sóror tecem um pacto, presente na ficção desde o início da narrativa, onde ambos demonstram sua curiosidade e carinho; mas indo além disto, pois se consideram a família dele nesta vida de exclusão. Ao identificarem-se com o "louco", em suas sensibilidades, desfazem a fronteira pré-existente entre sanidade e loucura, pois os três pareciam "falar a mesma língua": "Pedi a sóror Teresa que procurasse insinuar-me no espírito do enfermo, dizendo-lhe, sempre a meu respeito, coisas que pudessem chocar-lhe a sensibilidade, e dando-lhe a entender as minhas simpatias". (POMBO, 1970, p. 33) Embora tenha demorado um pouco para acontecer, após a entrada do narrador no manicômio como enfermo, ele realmente conseguiu a "amizade" de Fileto.

Mas a ficção, em dados momentos, mostrando-se inteira, aparece numa divergência aguda com a realidade concreta, como se fosse uma peça teatral. É o que apresenta o seguinte relato, relativo a mais um momento do cotidiano de Fileto, onde as palavras saindo em turbilhões são incompreensíveis e o gestual é característico:

Agora ele vai estudar. Não deixa os livros e a mesa de trabalho um instante, no correr do dia. Estuda e escreve sempre. Às 
vezes levanta-se para recitar o que escreveu. E chega então a emocionar-se, fica mais pálido ainda, estremece, agita-se todo, numas convulsões estranhas [...] quase que sorri olhando deslumbrado para fora e fazendo uns gestos misteriosos [...] Mas quando recita não fala alto: revessa as palavras atropeladamente [...]. E fica nos ares um vago sussurro, como as vozes que vêm de muito longe [...]. Depois, cai imóvel por algum tempo, a dizer frases ininteligíveis, ou a meditar...quase que conster-nado... (POMBO, 1970, p. 21)

Ou então, pode-se dizer que a ficção mesclou-se à realidade de um louco em pleno "surto", em plena crise, pois é assim que as pessoas foram acostumadas a imaginar e a olhar um paciente de hospício...

Desde os primórdios das representações humanas, a loucura aparece como se assemelhando a este estado: convulsivo, irracional, "teatralizado", com gestos estereotipados e "misteriosos". De Héracles, do hino de Homero ou da tragédia de Eurípedes, Héracles Enlouquecido ${ }^{9}$, passando pelas pacientes histéricas de Charcot na Salpêtrière de Paris do século XIX, até nossos dias povoando as centenas de manicômios contemporâneos, a loucura é vista sempre assim: possui uma representação "mais convincente que a realidade", pois esta, remetendo "para além do espelho da realidade objetiva", é "mais forte que o real". (GINZBURG, 2001)

No dizer de irmã Teresa, Fileto sofria de histerismo, ou neurastenia - conforme os médicos. Mas ela também não compreendia estes diagnósticos, pois eles não se adequavam à imagem que ela fazia dele. Além de tudo isto já revelado, havia uma outra coisa que a fazia cismar muito, e ela não entendia que fosse coisa que "doido gostasse de fazer". Nas redondezas do hospital, havia um piano, que Fileto gostava de escutar "como se fosse a

9 Várias lendas da Grécia antiga, assim como as tragédias, mencionam Hércules (nome do herói na Mitologia romana) tornado louco pela raiva de sua madrasta, Hera (ou Juno), esposa traída de Zeus (Júpier). Héracles (nome do mesmo herói na Mitologia grega) era filho da traição de Zeus com Alcmena, e desde pequeno apresentava descomunal força, tanto que matou sozinho a serpente que Hera mandou a seu leito. Mas sua loucura veio na forma de surtos violentos, inclusive de assassinatos; em um de seus tantos acessos, ele matou toda a sua prole com Mégara, a filha de Creonte, rei de Tebas, queimada no fogo. Hera não o poupou deste ataque de loucura, nem tivera piedade de Mégara e dos pobres inocentes filhos. Seu sentimento de vingança à traição de Zeus falou mais alto. A maior parte das lendas refere seus 12 trabalhos como forma de se escusar de tão terrível feito, de limpar da própria alma o crime que cometera e livrar-se do remorso que o atormentava. 
voz de alguém a lhe falar". Sempre à tardinha, ele ficava na janela à espera daquelas músicas que pareciam dominá-lo: "e quantas vezes, ao recolher como quem se escondia, eu lhe vi rolar pela face uma lágrima furtiva. A princípio, quis adivinhar tudo, mas... enganei-me: só a sua sensibilidade é que fazia aquilo”. (POMBO, 1970, p. 22)

A freira mostrava-se bastante sensível à condição de Fileto, ao observar e comentar a própria sensibilidade do moço em relação às coisas que costumava fazer no hospício. Ela não entendia o porquê dele ser considerado louco, e tentava repartir isto com aquele homem - o narrador sem nome - que se interessava cada vez mais pelo paciente, a ponto de fazer-se passar por doente, aos olhos do diretor do hospício, dos médicos, pacientes e, principalmente, de Fileto. ${ }^{10}$

Ambas as sensibilidades, supostamente contrárias à ciência médica de então, estão resumidas no pensamento do narrador, ao espantar-se mais uma vez com as declarações de sóror, do seguinte trecho:

Que ciência é esta que assim condena uma pobre criatura humana sem ouvi-la e abandona assim um espírito à solidão horrível de um hospício... Que ciência é esta que não cura os loucos!... Que sociedade então fizemos que não salva os perdidos![...] (POMBO, 1970)

Ele não compreendia como uma pessoa tal qual Fileto pudesse passar desapercebido lá dentro, como não havia no mundo quem se comovesse com aquela irremediável tristeza...

Assim, chegou o momento de sua ação. "É preciso não perder de vista aquele espírito". O narrador resolve ficar mais tempo dentro do manicômio, e pede a ajuda de sóror, a qual não poupa esforços para verem

10 O romance começa diretamente com o diálogo entre o narrador e sóror Teresa, cujo assunto era já Fileto. Com exceção da referida "nota de advertência" que consta na primeira edição de 1905, nenhuma outra introdução é feita, por parte do autor. Assim, não se sabe por que o narrador encontra-se no hospício, conversando com a irmã-enfermeira. Apenas ele está lá, e a partir disto, começa seu interesse pelo doente. Pode-se imaginar que ele fazia uma espécie de "trabalho assistencial voluntário", pois à página 26, quando ele ainda não estava internado, ele dizia que "no outro dia não era permitido visitas aos doentes" dando a entender que ele ia ali sempre nos horários de visitas do hospital. O que o escritor quis mostrar com isto? Os primeiros hospícios fundados no Brasil tinham esta característica assistencialista, pois se destacavam da Santa Casa de Misericórdia de algumas capitais, estando muitas vezes aos cuidados de irmãs caridosas. 
alcançadas as suas intenções. Como ele não fosse médico, como ela pensava no início, e não quisesse passar por enfermeiro, guarda ou servente, só ficaria mais tempo ali se fosse paciente.

Idéia maluca esta, de se passar por maluco! Mas ela é tratada, pelo autor, com grande "ingenuidade", pode-se dizer, com alegria e mesmo com certa euforia. Não houve, em momento algum da obra, uma só idéia preconceituosa, sinistra, oculta por parte do romancista, em relação ao narrador assumir-se como louco. Ao contrário, foi um recurso coerente para discutir esta temática, e não somente colocar em pauta as questões tão caras aos simbolistas brasileiros, como a religiosidade, a questão do símbolo e os parâmetros de sua estética. Mesmo sendo um dos temas preferenciais aos simbolistas brasileiros, a loucura e os "sujeitos desviantes", como dizem os críticos e mostram algumas obras, por que o autor escolheu-o desta forma?

E desde o momento do encontro de ambos, instauram-se longos diálogos no romance, onde todo o tipo de assunto é tratado, desde as questões religiosas que atormentam a ambos, até os questionamentos sobre a loucura e a medicina, que não vê no doente um ser humano para ser tratado e curado, mas sim alguém para ser excluído de uma sociedade que se quer "asséptica" dos seus "males".

Se existe uma imagem estereotipada sobre a loucura, no romance, é fruto da representação que se tinha sobre ela naquele momento histórico, a qual, parece, ele também queria discutir. Porém, quando o narrador fingese de louco, para poder ficar perto de seu objeto de interesse e "pesquisa", não é bem a "visão paródica" da doença que entra em cena, mas a "antivisão" da loucura, como contraponto àquela assumida pela sociedade.

Tem-se, portanto, nesta atitude ficcional, as "marcas de sensibilidade" do autor, consteladas no ato da escrita., remetendo, assim, à interioridade do texto literário. E de onde se percebe, ao mesmo tempo, na dialeticidade entre autor e seu processo criativo, os "traços de historicidade" - que remetem para fora do texto, ou seja, às representações sobre a loucura da sociedade da época. Não é difícil imaginar a intenção de Rocha Pombo, ou pelo menos supô-la, pois se parecer louco não era difícil, bastando com que o narrador fosse ele mesmo, dizendo, por exemplo, o que lhe bem aprouvesse, isto é, sendo sincero, então ser louco era algo que não deveria excluir socialmente o cidadão acometido por tais "condutas".

Reflexão esta que estaria, de certa forma, também coerente aos preceitos simbolistas, uma vez que estes tentavam, entre outras coisas, ir 
contra os modelos rígidos estabelecidos de ordem positivista na sociedade. Sob o "disfarce da loucura", o ficcionista consegue expor, tanto com Fileto como com o narrador, um debate estético - da estética simbolista - e com ela abrir horizontes de ordem geral, notadamente de ordem filosófica, incluindo na discussão o debate sobre a própria loucura - o que, sem dúvida extrapolava, na época, os círculos dos simbolistas.

Em outras palavras, as questões sobre a doença mental abrangiam questões sociais e culturais mais amplas, e eram, neste momento histórico, discutidas também no cerne da sociedade letrada e não somente nos gabinetes de políticos ou médicos. As sensibilidades sobre este tema, povoariam, aos poucos, nossa literatura, talvez desde a escritura de "O Alienista" de Machado de Assis em 1882. Outros escritores posteriores e importantes às letras brasileiras, como Lima Barreto, também teriam a loucura como objeto de sua ficção.

Esta foi a forma com a qual o escritor ficcionista, porém também historiador Rocha Pombo, conseguiu "recolher os membros espalhados do passado" e dar uma nova profundidade às questões da loucura, em seu tempo, através de seu romance. Mas não percebidas lá, por seus críticos em sua época, puderam ser resgatadas aqui...

\section{Referências}

BOSI, Alfredo. História concisa da Literatura Brasileira. São Paulo: Cultrix, 1994. CÂNDIDO, Antônio. Presença da literatura brasileira. São Paulo: Difusão Européia do Livro, 1964.

CARDIM, Elmano. Rocha Pombo: o escritor e o historiador. Rio de Janeiro: Gráfica editora Jornal do Comércio, 1958.

GINZBURG, Carlo. Olhos de madeira. São Paulo: Cia. das Letras, 2001.

JUNG. C. G. Tipos psicológicos. Rio de Janeiro: Zahar, 1981.

. O eи e o inconsciente. Petrópolis: Vozes, 1982. 
LEENHARDT, Jacques. As luzes da cidade - Notas sobre uma metáfora urbana em Jorge Amado. Texto apresentado no I Simpósio Nacional de História Cultural, em Porto Alegre (PUC-RS), set. 2002.

LEENHARDT, Jacques; PESAVENTO, S. Discurso histórico e narrativa literária. Campinas: Editora da Unicamp, 2000.

MEDEIROS, Tácito. Formação do modelo assistencial psiquiátrico no Brasil. Dissertação (Mestrado) - Instituto de Psiquiatria, Universidade Federal do Rio de Janeiro, Rio de Janeiro, 1977.

MOISÉS, Massaud. A Literatura brasileira: o Simbolismo (1893-1902). São Paulo: Cultrix, 1967, v. 4.

MURICY, Andrade. Panorama do Movimento Simbolista Brasileiro. Rio de Janeiro: Instituto Nacional do Livro, 1952.

PESAVENTO, Sandra. Em busca de uma outra história: imaginando o imaginário. Revista Brasileira de História, São Paulo: ANPUH/Marco Zero, v. 15. n. 29, 1995.

Com os olhos de Clio ou a literatura sob o olhar da história a partir do conto Alienista de Machado de Assis. Confrontos e Perspectivas, Revista Brasileira de História, São Paulo, ANPUH, v. 16, n. 31 e 32, p. 108-118, 1996.

Fronteiras da ficção: diálogos da história coma literatura. Coimbra: Faculdade de Letras, 2000.

POMBO, Rocha. No hospício. 2. ed. Rio de Janeiro: Instituto Nacional do Livro, 1970 .

PROPP, Vladimir. Morfologia do conto. Lisboa: Vega, [19-?].

SANTOS, Nádia Maria Weber. Histórias de vidas ausentes: a tênue fronteira entre a saúde e a doença mental. Passo Fundo: UPF, 2005.

. Histórias de sensibilidades: espaços e narrativas da loucura em três tempos - Brasil 1905, 1020, 1937. 397 p. Tese (Doutorado em História) - Instituto de Filosofia e Ciências Humanas. Universidade Federal do Rio Grande do Sul, 2005.

VON FRANZ, Marie Louise. Um método de interpretação psicológica. In:

A interpretação dos contos de fada. São Paulo: Paulinas, 1990. 